
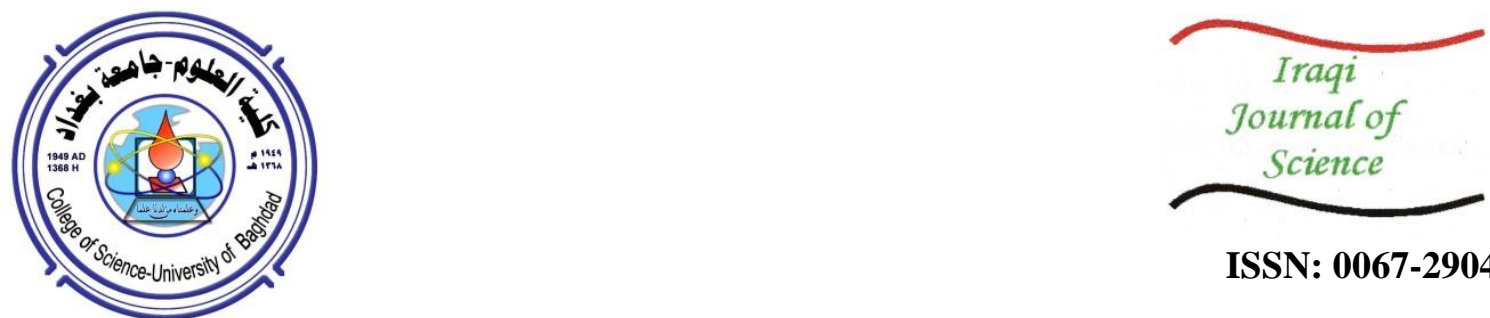

ISSN: 0067-2904

\title{
Dysregulation of Micro RNA-155 as a Biomarker in Iraqi Patients with Prostate Cancer
}

\author{
Jenan MJ. Elsaffar \\ Department of Biotechnology, College of Science, University of Baghdad
}

Received: 7/9/2020

Accepted: 25/11/2020

\begin{abstract}
Chronic inflammation can induce proliferative events and posttranslational DNA modifications in prostate tissues through oxidative stress. The miR-155 expression is abnormally increased in tumors. Therefore, this study aims to explore the clinical significance of serum TNF- $\alpha$ and IL- $1 \alpha$ as well as miR-155 expression in prostate cancer (PC) patients.

A total of 50 blood samples from patients diagnosed with prostate cancer were collected from the Oncology Department, Baghdad Teaching Hospital, along with samples from 50 healthy volunteers. Serum TNF- $\alpha$ and IL- $1 \alpha$ levels in Iraqi males with prostate cancer were estimated by using enzyme-linked immunosorbent assay (ELISA). The total RNA was extracted from all subjects and converted to cDNA using Stem-Loop technique and the expression was measured by real-time PCR (RTPCR) using SYBR Green with specific primers. The results showed that serum TNF$\alpha$ and IL-1 $\alpha$ levels were significantly higher in the clinical stage of tumor node metastasis (TNM) as compared to those in the control $(p<0.05)$. The miR- 155 level was significantly elevated in the patients compared with the control $(p<0.05)$, being positively correlated with advanced stages. It is concluded that circulating miR-155 could act as a promising marker for the diagnosis and prognosis of PC.
\end{abstract}

Key words :Prostate cancer; TNF- $\alpha$; IL-1 $\alpha$; mir-155; ELISA; RT-PCR.
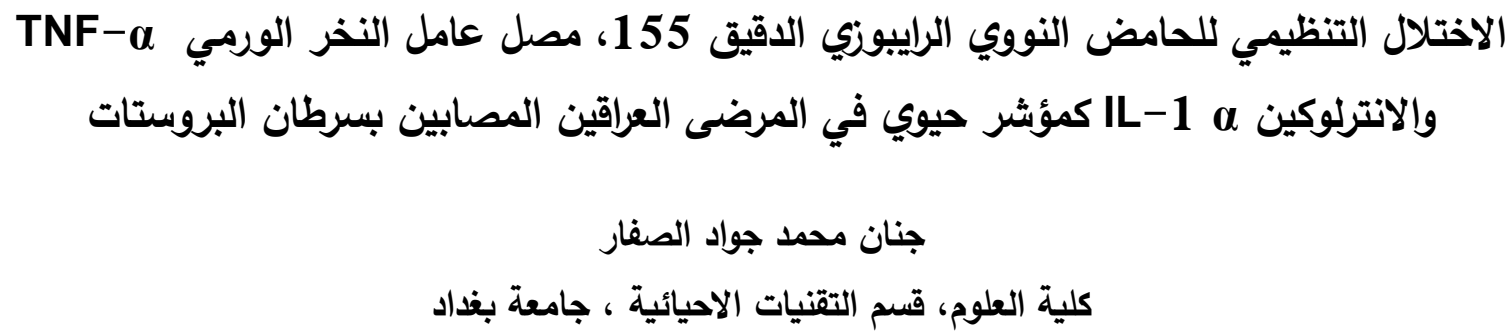

الخلاصه

يحفزالالتهاب المزمن تضاعف وتحويرات في الحمض النووي الدي اوكسي رايبوزي لعمليات ما بعد الترجمة

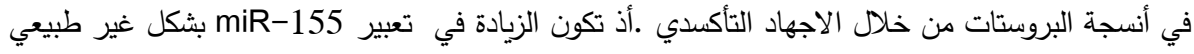

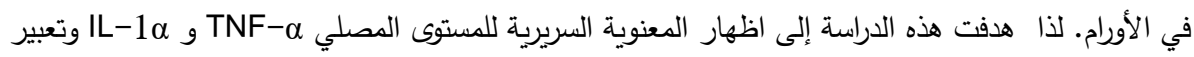

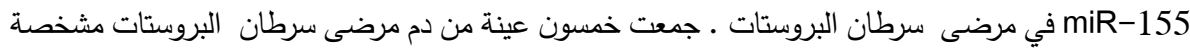

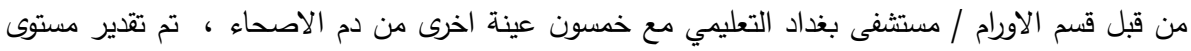

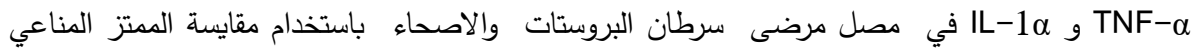

$$
\text { المرتبط بالإنزيم (ELISA). (2) }
$$

*Email: jenan.elsaffar@yahoo.com 


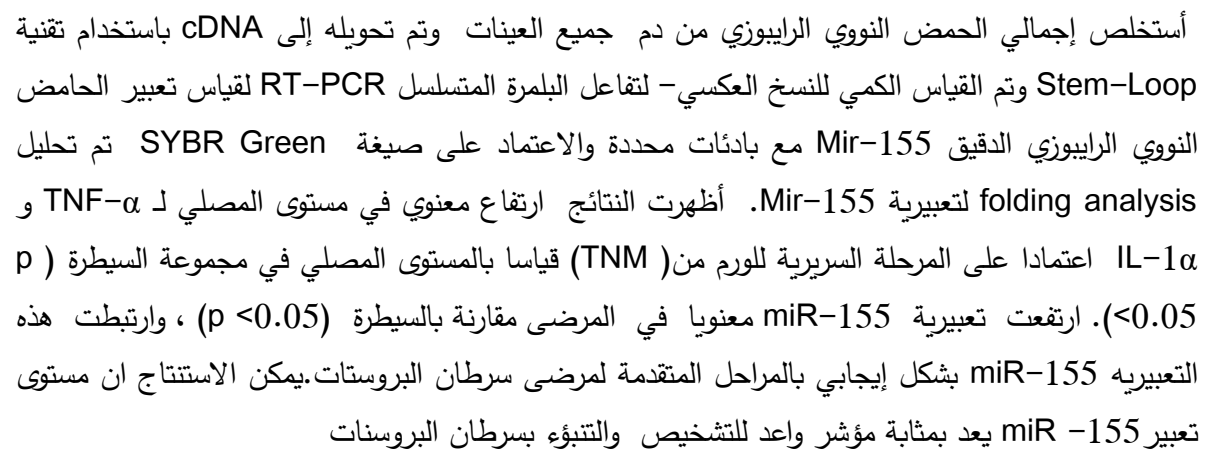

\section{Introduction}

Prostate cancer is a popular male cancer that involves various phenotypes, ranging from indolent to highly aggressive. Currently utilized markers for prognostic and diagnostic purposes have several limitations, while new biomarkers need to stratify and assign optimal therapies to patients, taking into account potential genetic and epigenetic differences (1). Micro-RNAs ( miRNAs) are non-coding small RNA sequences that have been revealed to control the expression of the tumorigenesis genes involved in PC development (2). Present evidence indicates that several mammalian genome-encoded miRNAs influence cellular biology by targeting specific mRNA subsets, involving those related to tumorigenesis, differentiation, apoptosis, and proliferation (3). The miRNAs repress the expression of target genes at the post-transcription level by binding target sequences of mRNA to the $3^{\prime}$ end of the untranslated region (3' UTR), through fostering degradation of RNA or inhibiting translation. In cancer, miRNAs target and regulate the expression of multiple target genes, including the downstream effectors and suppressors of tumor and of oncogenic factors (4). TNF- $\alpha$ is a pleiotropic cytokine which, similar to IL-1 $\alpha$, has been shown to be related with the progression of cancer. It is of notice that many androgen-insensitive PC cells are insensitive to TNF- $\alpha$. This is probably due to the up-regulation of several anti-apoptotic genes involved in the autocrine and paracrine network that modifies the cellular activities in PC. These involve the nuclear factor-kappa B (NF- $\mathrm{kB})(5)$. TNF- $\alpha$ is related to a family of transcription factors with antitumor activities which are released from prostate cancer cells themselves while from associate macrophages after a relapse in disease (5). Several previous studies reported that patients with hormonerefractory PC exhibit elevated levels of serum TNF- $\alpha$ as compared with untreated patients (6). In addition, TNF- $\alpha$ facilitates the spread of PC from the metastatic lymph nodes by stimulating the CCL21 / CCR-7 axis, resulting in the migration of PC cells, through protein kinase p-38 phosphorylation (7). IL- $1 \alpha$ is a regulatory cytokine which stimulates numerous transcription factors, such as the activator protein (AP-1) and NF- $\mathrm{kB}$, which promote the expression of multiple genes involved in angiogenesis, proliferation, and survival of cells (8). These two cytokines are overlapping with several biological properties, including prostate cancer development Micro RNA-155(miR-155) is overexpressed in many cancer conditions such as PC, breast cancer, and other tumors. Therefore, this study aimed to explore the clinical significance of TNF- $\alpha$ and IL- $1 \alpha$, combined miR-155, in the early diagnosis of PC.

\section{Materials and Methods}

\section{Subjects}

Fifty PC patients diagnosed by histopathological examination at different stages (30 at early stages (I-II) and 20 at advanced stages (III-I V)) were enrolled in AL-Kindy Teaching Hospital- Histological Department, Baghdad, Iraq, from September 2018 until May 2019. Their mean age was $49.8 \pm 57.7$, ranged 45-70 years. Criteria of inclusion included primary PC confirmed by pathology, without radiotherapy, chemotherapy, surgery, or other treatments.

Criteria of exclusion included recurrent PC treated by chemotherapy, radiotherapy, or surgery. Cases combined with other diseases were also excluded, for example complications of malignant tumor, systemic immune diseases, secondary renal hypertension, metabolic bone diseases, pulmonary fibrosis, severe disease of kidney and liver, malignant tumors, and infectious diseases. Fifty healthy volunteers were established as controls, who were age-matched to patients. To investigate circulating miRNA and serum cytokine levels in patients and controls, $5 \mathrm{ml}$ of peripheral blood was separated into $2.5 \mathrm{ml}$ in EDTA tubes for gene expression and $2.5 \mathrm{ml}$ in gel tubes for serum cytokines.

Estimation of Serum Levels of TNF- $\alpha$ and IL-1 $\alpha$ 
TNF- $\alpha$ level was measured by TNF- $\alpha$ human ELISA kit (Demeditec Diagnostics Gmb-H; Germany). IL-1 $\alpha$ was measured by a kit purchased from Thermo Fisher Scientific, Bender Med-Systems Gmb-H, Austria).

\section{Measurement of the Expression of miR-155}

RNA was isolated from samples using Direct-zol ${ }^{\mathrm{TM}}$ RNA MiniPrep, R2051, kit (Zymo Research / USA) according to the instructions of the manufacturers. The RNA sample was eluted with nuclease free water $(20 \mu \mathrm{l})$. For cDNA synthesis reaction, the Prime Script-TM RT reagent kit was utilized. The forward primer 5' CGC GCG TTA ATG CTA ATC 3' and reverse primer 5' GTC GTA TCC AGT GCA GGG TCC GAG GTA TTC GCA CTG GAT ACG ACA ACCCC 3' were used. Briefly, each reverse transcription reaction consisted of a final concentration of $100 \mathrm{ng} / \mu \mathrm{l}$ total RNA, $4.5 \mu 1$ nuclease free water, $0.5 \mu l$ synthetic stem-loop primer, and $2 \mu 120 \mathrm{X}$ reaction buffer of prime script. The reaction of RT-PCR was performed using SaCycler-96 thermal cycler (SACACE, Italy) for $15 \mathrm{~min}$ at $42{ }^{\circ} \mathrm{C}$, followed by heat-inactivation for $1 \mathrm{~min}$ at $85^{\circ} \mathrm{C}$, and storage at $4^{\circ} \mathrm{C}$. For quantitative PCR (q PCR), the reaction mixture of $20 \mu 1$ was prepared by using KAPA SYBR®FAST Universal PCR master mix (KAPA, USA) as recommended by the manufacturer. Briefly, a mix of $0.5 \mu 1$ of each of forward and reverse primers, $4 \mu 1$ of diluted cDNA $(1: 4)$, and $10 \mu 1$ of 2 X SYBR Green master mix were added, then the volume was completed to $20 \mu \mathrm{l}$ by the addition of $5 \mu 1$ of nuclease free water. U6 MI-RNA was used as an endogenous control. The q PCR was performed for $7 \mathrm{~min}$ at $95^{\circ} \mathrm{C}$ for activation of polymerase then for $10 \mathrm{sec}$ at $95^{\circ} \mathrm{C}$ by 45 cycles and for one min of $60{ }^{\circ} \mathrm{C}$. Finally, the analysis of melting curve was performed based on ads DNA dissociation characteristics through cycles with increasing denaturation temperature.

\section{Statistical analysis}

A statistical software (SPSS 10.4) was used for the analysis of data. Measured data were expressed as mean \pm Standard Error (SE). Differences between means were assessed by independent samples $\mathrm{T}$ test. Differences with a probability value that equals or less than 0.05 were considered significant. The fold change was calculated by the following equations:

1. $\Delta \mathrm{CT}=\mathrm{CT}$ of target gene $-\mathrm{CT}$ of $\mathrm{U}$ gene.

2. $\Delta \Delta \mathrm{CT}=\Delta \mathrm{CT}$ of each sample - average control $\Delta \mathrm{CT}$.

3. Fold change $=\mathbf{2}^{-\Delta \Delta \mathrm{Ct}}$

\section{Results}

\section{Serum TNF- $\alpha$}

The levels of TNF- $\alpha$ were measured in the serum samples of PC patients and control $(78.55 \pm 6.81 \mathrm{vs}$ $12.38 \pm 4.33 \mathrm{pg} / \mathrm{ml})$, with significant differences found $(p<0.05)$. A significant increase was observed in the early and advanced PC stages compared with the control, as shown in Figure- 1 . There was a higher TNF- $\alpha$ level in the advanced stages ( $44.98 \pm 4.49 \mathrm{pg} / \mathrm{ml}$ ) than that in the early stages of the disease $(33.56 \pm 3.82 \mathrm{pg} / \mathrm{ml})(\mathrm{p}<0.05)$.

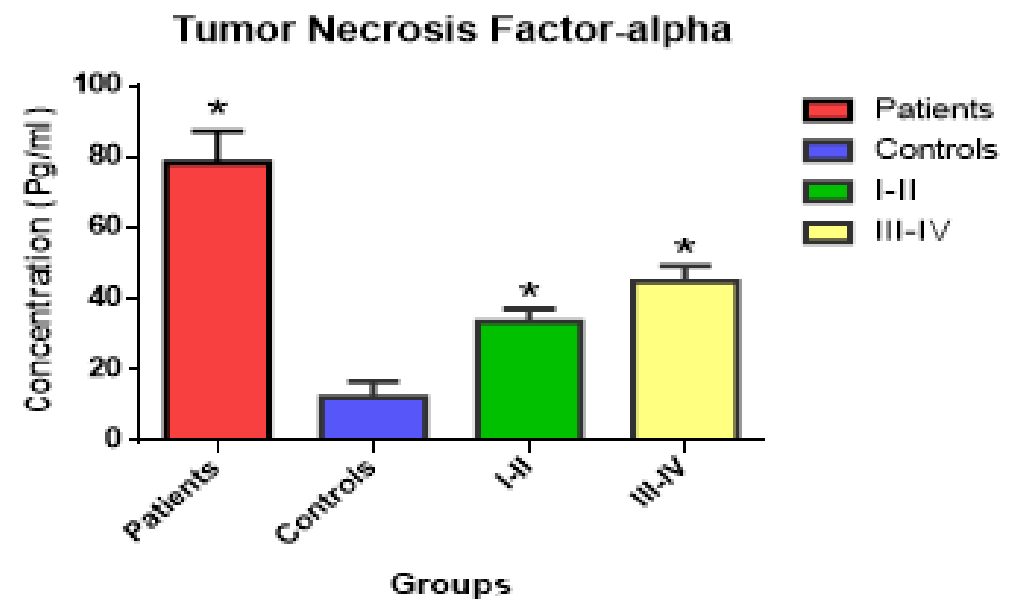

Figure 1- Serum levels of TNF- $\alpha$ in prostate cancer patients and healthy controls. 


\section{Serum IL-1 $\alpha$}

The statistical analysis showed significant differences with respect to serum levels of IL-1 $\alpha$ through the various clinical stages of PC in the patients. The levels were found to be significantly increased in patients of PC as compared to healthy controls $(37.85 \pm 4.65 v s .8 .55 \pm 1.87 \mathrm{pg} / \mathrm{mL})$. In the advanced stages, IL- $1 \alpha$ level was significantly higher $(20.49 \pm 2.62 \mathrm{pg} / \mathrm{ml})$ compared with that in the early stages $(17.36 \pm 2.03 \mathrm{pg} / \mathrm{ml})$, as demonstrated in Figure-2.

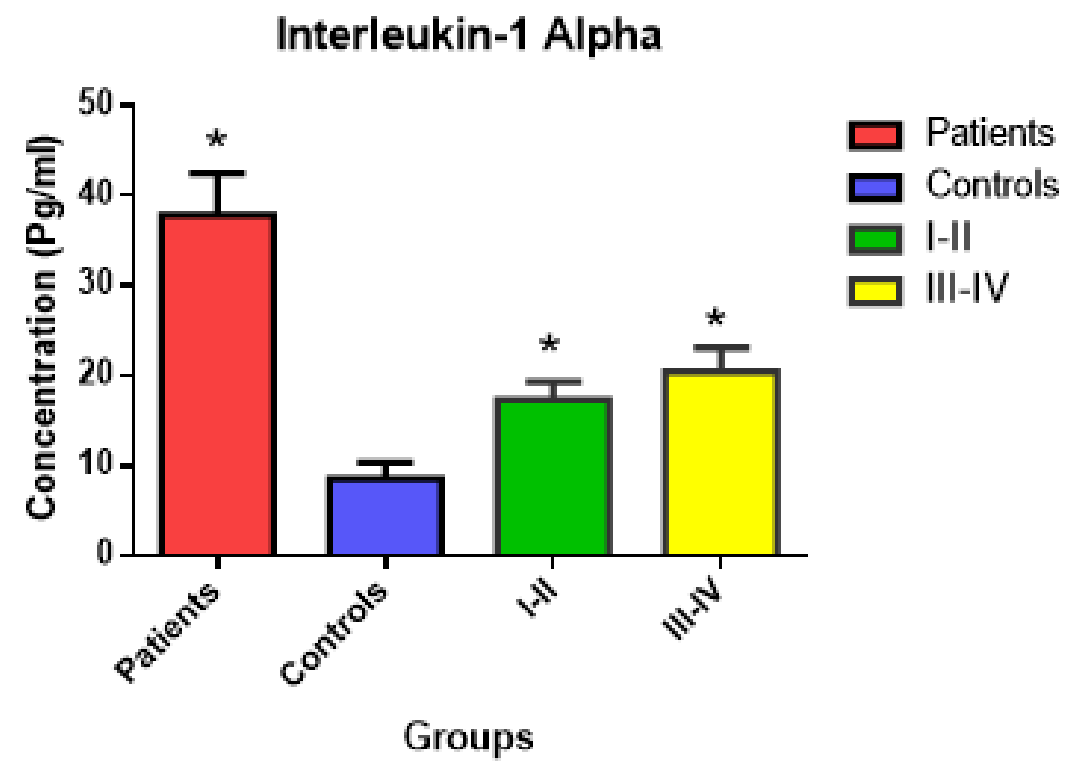

Figure 2- Serum levels of IL-1 $\alpha$ in prostate cancer patients and healthy controls.

\section{Mir-155 Gene Expression in Prostate Cancer at Early and Advance Stages}

The gene expression level of mir-155 was tested using RT-PCR after converting the RNA into cDNA using a specific stem loop primer that lengthen the targeted miRNA. The resulted curves are shown in (Figure-3). Then the fold change was calculated using the Livak method (9).

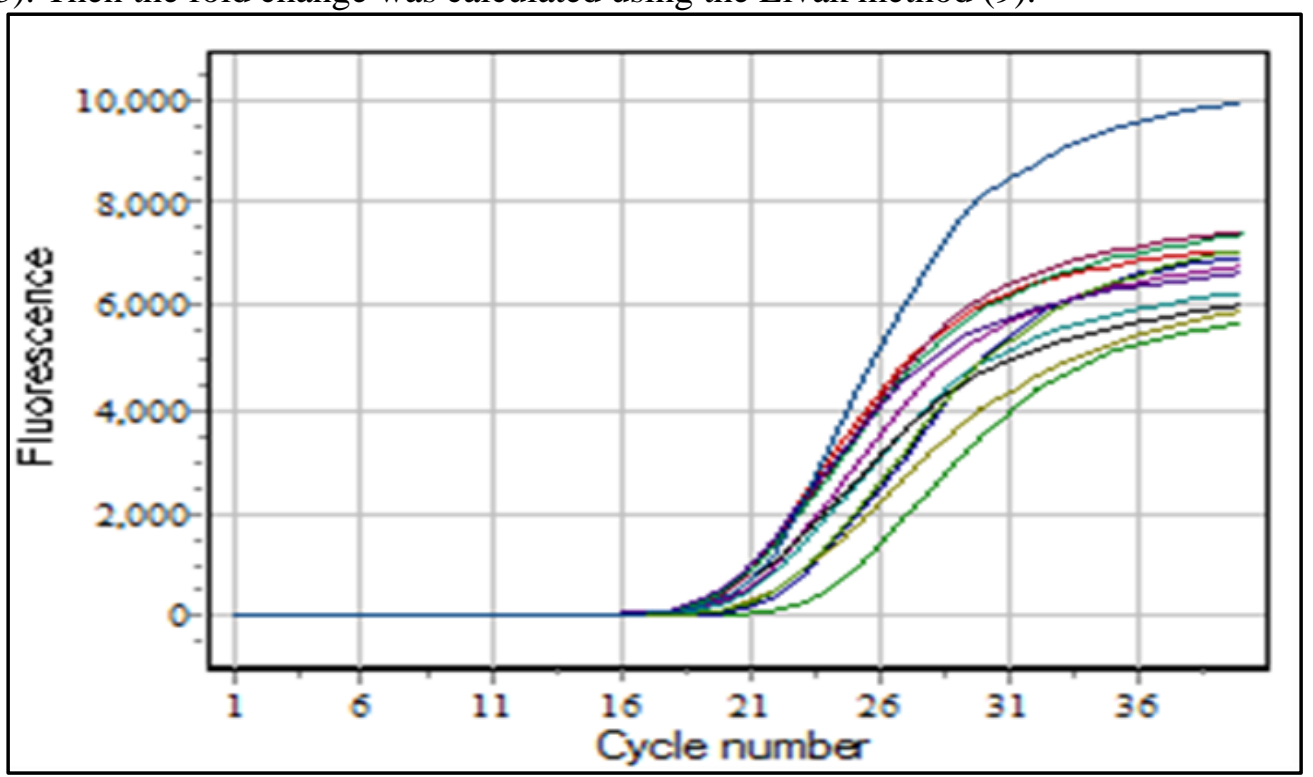

Figure 3- Rt-PCR results of related MicroRNAs expression tested by threshold cycle (Ct).

The results revealed that mir-155 expression was significantly higher in PC patients compared to controls $(p=0.001)$, as shown in Table-1.

Table 1- mir-155 gene expression in PC patients and control 


\begin{tabular}{|c|c|c|c|c|c|}
\hline miRNA & $\begin{array}{c}\text { Mean } \mathbf{\Delta C t} \pm \\
\text { SE for } \\
\text { controls }\end{array}$ & $\begin{array}{c}\text { Mean } \Delta \mathbf{C C t} \pm \\
\mathbf{S E} \text { for } \\
\text { patients }\end{array}$ & p- value & $\boldsymbol{\Delta} \mathbf{\Delta C t}$ & $\begin{array}{c}\text { Folding } \\
\text { expression }\end{array}$ \\
\hline miRNA-155 & $28.1 \pm 1.26$ & $23.7 \pm 1.37$ & 0.001 & -4.31 & 19.83 \\
\hline
\end{tabular}

The gene expressions of mir-155 level was significantly higher in patients with the advanced stages (III and IV), than in patients with the early stages (I and II), as shown in Figure- 4.

\section{Mir-155 Expression}

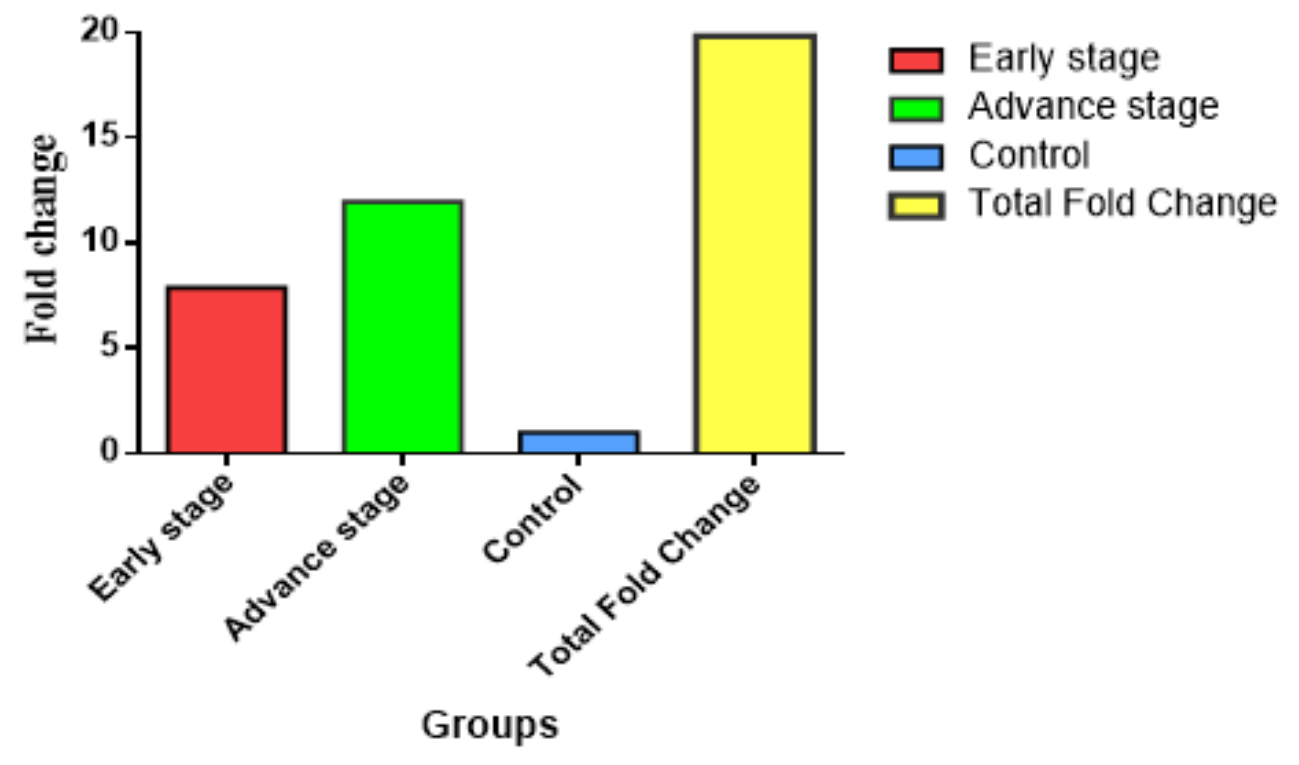

Figure 4- The expression of miR-155 in early and advanced stages of prostate cancer.

\section{Discussion}

Elevated serum cytokine levels have been previously described in PC malignant and benign prostate hyperplasia $[5,10]$. We report here elevated TNF- $\alpha$ and IL- $1 \alpha$ serum levels and overexpression of mir155 in patients with PC as compared with controls. Several studies descried that levels of certain cytokines are increased in prostate cancer conditions $[11,12]$. In patients with progressive PC, levels of both TNF- $\alpha$ and IL-1 $\alpha$ elevated and further raised ( $p>0.05$ ) at symptomatic progression of the disease. These cytokines may therefore offer additional markers to prostate specific antigen(PSA) that reproduce PC activity. Our results confirm those of previous studies [5, 7, 13]. The production of IL-1 $\alpha$ was associated with resistance to exogenous anti-proliferative stimuli and increase in the constitutive production of other inflammatory cytokines in an autocrine manner, which may be important for assessing malignancy (8). Similar increase in the level of IL-1 $\alpha$ in PC patients in both early and advanced stages was previously reported (14), while another study reported no immunoreactions to IL$1 \alpha$ in normal PC patients, in contrast to those in advanced stages (8). However, larger sample size is needed to confirm this association.

The expression of miR-155 was established to be up-regulated in many types of cancer, being involved in the development of lung and breast cancers as well as leukemia[15, 16]. The biological role of miR-155 in PC has not been fully investigated. In the present study, the in vivo expression of miR155 was investigated in the peripheral blood of PC patients for the first time. The results showed that miR-155 was significantly up-regulated in the patients, a finding that is identical to that reported by an earlier study (17), which reported mir-155 overexpression in PC cell line. Many studies have established TNF- $\alpha$ and IL- $1 \alpha$ as biomarkers for prostate cancer diagnosis; however, the significant prognosis is unpredictable, and there is a need for new biomarkers to stratify patients and assign them optimal therapies by taking into account the potential of epigenetic and genetic differences, including those in 
microRNAs. The expression of miRNAs is important in cell cycle arrest, apoptosis, and proliferation of tumor cells. Additionally, human PC cells transfected with miR-155 inhibitor showed reduced proliferation, suggesting that miR-155 promoted PC cell proliferation in vitro (18). It is concluded that inflammation may play a role in prostate cancer development.

\section{References}

1. Fu W, Madan E, Yee M, Zhang H. 2012. Progress of molecular targeted therapies for prostate cancers. Biochimica et Biophysica Acta - Reviews on Cancer. 1825: 140-52.

2. Bertoli G, Cava C, Castiglioni I. 2016. MicroRNAs as biomarkers for diagnosis, Prognosis and theranostics in prostate cancer. International Journal of Molecular Sciences. MDPI AG.17.

3. Moustafa AA, Kim H, Albeltagy RS, El-Habit OH, Abdel-Mageed AB. 2018. MicroRNAs in prostate cancer: From function to biomarker discovery. Experimental Biology and Medicine. SAGE Publications Inc. 243: 817-25.

4. Zheng T, Wang J, Chen X, Liu L. 2010. Role of microRNA in anticancer drug resistance. International Journal of Cancer. 126: 2-10.

5. Michalaki V, Syrigos K, Charles P, Waxman J. 2020. Serum levels of IL-6 and TNF- $\alpha$ correlate with clinicopathological features and patient survival in patients with prostate cancer. Br J Cancer [Internet]. 2004 Jun 14 [cited 2020 Mar 12]; 90(12): 2312-6. Available from: http://www.ncbi.nlm.nih.gov/pubmed/15150588

6. Muenchen HJ, Lin D-L, Walsh MA, Keller ET, Pienta KJ. 2000. Tumor Necrosis Factor- $\alpha$-induced Apoptosis in Prostate Cancer Cells through Inhibition of Nuclear Factor- $\kappa \mathrm{B}$ by an I $\mathrm{KB} \alpha$ "SuperRepressor." Clin Cancer Res. 2000; 6(5).

7. Maolake A, Izumi K, Natsagdorj A, Iwamoto H, Kadomoto S, Makino T, et al. 2018. Tumor necrosis factor- $\alpha$ induces prostate cancer cell migration in lymphatic metastasis through CCR7 upregulation. Cancer Sci. 2018 May 1; 109(5): 1524-31.

8. Ricote M, García-Tuñón I, Bethencourt FR, Fraile B, Paniagua R, Royuela M. 2020. Interleukin-1 (IL-1 $\alpha$ and IL-1 $\beta$ ) and Its Receptors (IL-1RI, IL-1RII, and IL-1Ra) in Prostate Carcinoma. Cancer [Internet]. 2004 Apr 1 [cited 2020 Mar 12]; 100(7): 1388-96. Available from: http://www.ncbi.nlm.nih.gov/pubmed/15042672

9. Livak KJ, Schmittgen TD. 2001. Analysis of Relative Gene Expression Data Using Real-Time Quantitative PCR and the 2 C T Method. METHODS. 25: 402-8.

10. Wang X, Yang L, Huang F, Zhang Q, Liu S, Ma L, et al. 2017. Inflammatory cytokines IL-17 and TNF- $\alpha$ up-regulate PD-L1 expression in human prostate and colon cancer cells. Immunol Lett. 2017 Apr 1; 184: 7-14.

11. Wang J, Cao C, Luo H, Xiong S, Xu Y, Xiong W. 2019. Tumour necrosis factor alpha -308G/A polymorphism and risk of the four most frequent cancers: A meta-analysis. Int J 3. Singh J, Sohal SS, Lim A, Duncan H, Thachil T, De Ieso P. Cytokines expression levels from tissue, plasma or serum as promising clinical biomarkers in adenocarcinoma of the prostate: a systematic review of recent findings. Ann Transl Med. 2019; 7(11).

12. Mizokami A, Gotoh A, Yamada H, Keller ET, Matsumoto T. 2000. Tumor necrosis factor-alpha represses androgen sensitivity in the LNCaP prostate cancer cell line. J Urol [Internet]. 2000 Sep [cited 2019 Oct 20]; 164(3 Pt 1): 800-5. Available from: http://www.ncbi. nlm.nih.gov/pubmed /10953159

13. Singh,J.,SohalS.S.,Lim,A.,Duncan,H.,Thachil,T.,\&Deleso,P.(2019)Cytokinese expression levels from tissue, plasma or serum as promising clinical biomarkers in adenocarcinoma of the prostate: asystematic review of recent findings. Annals of translational medicine.

14. Ferrer FA., Miller LJ., Andrawis RI., Kurtzman SH., Albertsen PC., Laudone VP., et al. 1998. Angiogenesis and prostate cancer: In vivo and in vitro expression of angiogenesis factors by prostate cancer cells. Urology. 1998 Jan 1; 51(1): 161-7.

15. Yang M., Shen H., Qiu C., Ni Y., Wang L., Dong W., et al. 2020. High expression of miR-21 and miR-155 predicts recurrence and unfavourable survival in non-small cell lung cancer. Eur J Cancer [Internet]. 2013 Feb [cited 2020 Mar 17]; 49(3): 604-15. Available from:http://www. ncbi.nlm.nih.gov/pubmed/23099007.

16. Jin,W., Fei, X., Wang,X., Chen,F.,\&Song,Y.,( 2020). Circulating miRNAs as Biomarkers for Prostate Cancer Diagnosis in Subjucts with Benign Prostate Hyperplasia. JOURNAL OF 
Immunology Research ,2020.

17. Cai ZK, Chen Q, Chen YB, Gu M, Zheng DC, Zhou J, et al. 2015. MicroRNA-155 promotes the proliferation of prostate cancer cells by targeting annexin 7. Mol Med Rep. 2015 Jan 1; 11(1): 5338.

18. Budd WT, Seashols-Williams SJ, Clark GC, Weaver D, Calvert V, Petricoin E, et al. 2015. Dual action of miR-125b as a tumor suppressor and OncomiR-22 promotes prostate cancer tumorigenesis. PLoS One. 2015 Nov 6; 10(11). 